\author{
E. Baliousis, S. Samaropoulou \& P. Bareka
}

\title{
Micromorphological study of some Trifolium taxa (Fabaceae) seeds from Greece and its systematic significance
}

\begin{abstract}
Baliousis, E., Samaropoulou, S. \& Bareka, P.: Micromorphological study of some Trifolium taxa (Fabaceae) seeds from Greece and its systematic significance. — Fl. Medit. 31: 247-259. 2021. - ISSN: 1120-4052 printed, 2240-4538 online.

Greece is considered a diversity center for the genus Trifolium L. (Fabaceae), which is represented in the country by 95 taxa. However, the classification of the genus may vary according to different taxonomic approaches. The current study aims to contribute to the study of the genus by describing the seed coat surface of 23 Trifolium taxa that were collected in various localities of southern Greece. The seeds were obtained from herbarium specimens and observed with Scanning Electron Microscope.
\end{abstract}

Key words: SEM, taxonomy, Faboideae, biosystematics.

\section{Introduction}

The genus Trifolium L. (Fabaceae) consists of approximately 255 species (Smýkal \& al. 2015; Scoppola \& al. 2018), distributed throughout the temperate and subtropical regions of the world, even though representatives of the genus can also be found restricted to the montane and alpine zones in the tropics of West Africa and South America (Zohary \& Heller 1984). Greece, along with Anatolia, constitute a diversity center for the genus Trifolium (Zohary \& Heller 1984), which is represented in the country by 95 taxa (species and subspecies), including 8 endemic ones (Dimopoulos \& al. 2013). The number of Trifolium taxa frequently varies among the authors depending on their taxonomical approach, the progress of botanical explorations and the increase of systematic and evolutionary studies (Samaropoulou \& al. 2019).

Trifolium taxa in Greece occur in various types of natural, semi-natural and anthropogenic habitats, generally at places that are exposed to high solar radiation (Ellison \& al. 2006; Samaropoulou \& al. 2019).

A significant number of publications are dealing with the seed coat morphological and micromorphological characteristics of various families and their systematic implications. Among the first relative studies concerning genera of the Fabaceae include those of Lersten (1979, 1981), Lersten \& Gunn (1982), Manning \& van Staden (1987) and Small \& al. (1990). 
In the framework of the revision of the genus Trifolium, Zohary \& Heller (1984) examined the seed coat surface of 24 species, providing relative SEM photographs for 8 of them and they described 5 different types of seed coat patterns. According to Pinar \& al. (2001) diploid and tetraploid forms of Trifolium pratense L. can be distinguished by their seed coat ornamentation. Taia (2004) examined eight Trifolium species and recognised three seed coat patterns, while Salimpour \& al. (2007) studied the seed morphology of seven Trifolium taxa from Iran. Zorić \& al. (2010) studied 38 Trifolium species and separated them into eight groups based on seed coat morphological characters.

However, the study of seed characteristics of this taxonomically, ecologically and economically important genus remains incomplete especially concerning Greek taxa. The present study aims to contribute to the taxonomy of the genus Trifolium by describing the seed coat surface patterns of 23 taxa from Greek populations.

\section{Materials and Methods}

Material was obtained from herbarium specimens collected by the first author from various localities of southern Greece and deposited in ACA (Table 1). The seeds were put directly onto carbon adhesive discs on aluminum stubs and sputter coated with approximately $25 \mathrm{~nm}$ of gold. The observation was carried out with a FEI Quanta Inspect SEM and it took place in the Electron Microscopy and Nanomaterials Laboratory, Department of Materials Science, Demokritos Institute. At least 15 seeds of each taxon were analysed and seed length and width, aspect ratio (L/W), shape and coat surface are given.

The determination of the seed shape follows Zorić \& al. (2010) and takes into consideration aspect ratio and the length of the radical lobe. Seeds are characterised as round (aspect ratio up to 1.19), ovoid (aspect ratio 1.20-1.39), elongated-ovoid (aspect ratio more than 1.40) and, in the case of the radicle lobe being very prominent, heart-shaped.

The terminology of the coat surface follows Lersten (1981), Lersten \& Gunn (1982), Manning \& van Staden (1987) and Small \& al. (1990).

\section{Results and Discussion}

The present study examines the seed micromorphological features in 23 taxa of the genus Trifolium including representatives from the major sections with Mediterranean floristic elements. Seed morphometric characters, shape and coat pattern is reported for the first time for 10 species, among them, the Greek endemic Trifolium aurantiacum. At least x5000 magnification is required in order to obtain a precise idea of the seed surface micromorphology and avoid inconsistencies among various reports concerning the same species. As mentioned by Lersten (1979), seeds of most Fabaceae are smooth and featureless at low magnification. The seed coat surface micromorphology of the examined taxa is demonstrated in Figs 1-6.

The seeds of the studied taxa vary in size from $0.8803 \mathrm{~mm}$ to $2.3333 \mathrm{~mm}$ in length and from $0.6092 \mathrm{~mm}$ to $1.9245 \mathrm{~mm}$ in width. Although Trifolium subterraneum has the largest seed dimensions measured, its aspect ratio is one of the smallest ones (1.1458). However, 
Table 1. List of examined taxa.

\begin{tabular}{|c|c|c|}
\hline Taxon & Locality & Voucher No \\
\hline Trifolium angustifolium $\mathrm{L}$. & $\begin{array}{l}\text { Attiki, Mt. Pendelikon, hills N of Dionisovouni summit, near the chapel of } \\
\text { Agios Ioannis, road margins, } 490 \mathrm{~m} \text {, } 4 \text { Jun } 2018\end{array}$ & 12929 \\
\hline Trifolium arvense $\mathrm{L}$. & $\begin{array}{l}\text { Attiki, municipality of Thrakomakedones, ca. } 1 \text { km ESE of the monastery of } \\
\text { Kimiseos Theotokou, recently burnt Pinus halepensis Mill. forest, coarse- } \\
\text { grained fluviolacustrine formations on Parnitha piedmont, } 350 \mathrm{~m}, 4 \text { May } \\
2018\end{array}$ & 12908 \\
\hline $\begin{array}{l}\text { Trifolium aurantiacum } \\
\text { Boiss. \& Spruner }\end{array}$ & $\begin{array}{l}\text { Peloponnisos, Mt. Aphrodisio, ca. } 0.5 \text { km SE of Dechouni village, Quercus } \\
\text { coccifera L. scrub, limestones, } 850 \text { m, } 24 \text { May } 2013\end{array}$ & 8154 \\
\hline Trifolium boissieri Guss. & $\begin{array}{l}\text { Kiklades, the island of Kea, path margins on the way to Karthaia } \\
\text { archaeological site, } 50 \mathrm{~m}, 27 \text { May } 2018\end{array}$ & 12680 \\
\hline Trifolium campestre Schreb. & $\begin{array}{l}\text { Attiki, municipality of Thrakomakedones, ca. } 1 \text { km ESE of the monastery of } \\
\text { Kimiseos Theotokou, recently burnt Pinus halepensis Mill. forest, coarse- } \\
\text { grained fluviolacustrine formations on Parnitha piedmont, } 350 \mathrm{~m}, 4 \text { May } \\
2018\end{array}$ & 12906 \\
\hline Trifolium cherleri $\mathrm{L}$. & $\begin{array}{l}\text { Peloponnisos, Mt. Aphrodisio, ca. } 1 \text { km S of Nasia village, forest roadsides, } \\
700-800 \text { m, } 26 \text { May } 2013\end{array}$ & 8699 \\
\hline Trifolium fragiferum $\mathrm{L}$. & $\begin{array}{l}\text { Attiki, Stamata village, near the chapel of Agia Paraskevi, damp places by } \\
\text { Platanus orientalis L. stream, } 350 \mathrm{~m} \text {. } 12 \text { Jul } 2007\end{array}$ & 4000 \\
\hline Trifolium glomeratum $\mathrm{L}$. & $\begin{array}{l}\text { Peloponnisos, Mt. Aphrodisio, ca. } 1 \mathrm{Km} \mathrm{S} \text { of Nasia village, Quercus } \\
\text { frainetto Ten. forest and roadsides, radiolarites, } 700-800 \text { m, } 26 \text { May } 2013\end{array}$ & 8749 \\
\hline $\begin{array}{l}\text { Trifolium grandiflorum } \\
\text { Schreb. }\end{array}$ & $\begin{array}{l}\text { Kiklades, the island of Kea, path margins on the way to Karthaia } \\
\text { archaeological site, } 20-100 \mathrm{~m}, 27 \text { May } 2018\end{array}$ & 12678 \\
\hline Trifolium hirtum All. & $\begin{array}{l}\text { Attiki, Mt. Pendelikon, in the locality Chrisouli Rachi, schistose slopes with } \\
\text { phrygana, } 650 \text { m, } 19 \text { May } 2002\end{array}$ & 858 \\
\hline Trifolium lappaceum $\mathrm{L}$. & $\begin{array}{l}\text { Peloponnisos, Mt. Aphrodisio, between Kondovazena and the crossroad to } \\
\text { Peleki village, damp places by the roadsides, } 650 \mathrm{~m}, 25 \text { May } 2013\end{array}$ & 8567 \\
\hline $\begin{array}{l}\text { Trifolium leucanthum } \mathrm{M} . \\
\text { Bieb. }\end{array}$ & $\begin{array}{l}\text { Peloponnisos, Mt. Aphrodisio, ca. } 1 \text { km S of Nasia village, forest roadsides, } \\
\text { 700-800 m, } 26 \text { May } 2013\end{array}$ & 8698 \\
\hline Trifolium nigrescens Viv. & $\begin{array}{l}\text { Kiklades, the island of Kea, path margins on the way to Karthaia } \\
\text { archaeological site, } 20-100 \mathrm{~m}, 27 \text { May } 2018\end{array}$ & 12682 \\
\hline Trifolium patens Schreb. & $\begin{array}{l}\text { Peloponnisos, Mt. Aphrodisio, between Dafni and the crossroad to Nasia, } \\
\text { roadsides, } 550-600 \text { m, } 26 \text { May } 2013\end{array}$ & 8645 \\
\hline Trifolium physodes $\mathrm{M}$. Bieb. & $\begin{array}{l}\text { Attiki, Mt. Pendelikon, near the water tanks of Dionisos municipality, path } \\
\text { margins in densely regenerated Pinus halepensis Mill. forest, } 550 \text { m, } 3 \text { Jun } \\
2007\end{array}$ & 3773 \\
\hline $\begin{array}{l}\text { Trifolium pignantii Fauché } \\
\text { \& Chaub. }\end{array}$ & $\begin{array}{l}\text { Peloponnisos, Mt. Aphrodisio, between Pera Vachlia village and the dam of } \\
\text { Ladona lake, Quercus frainetto Ten. forest, mainly radiolarites, } 500 \mathrm{~m}, 25 \\
\text { May } 2013\end{array}$ & 8633 \\
\hline Trifolium repens $\mathrm{L}$. & $\begin{array}{l}\text { Peloponnisos, Mt. Aphrodisio, Dechouneika village, } 620 \text { m, walnut orchard, } \\
620 \text { m, } 24 \text { May } 2013\end{array}$ & 8066 \\
\hline $\begin{array}{l}\text { Trifolium resupinatum } \mathrm{L} . \\
\text { subsp. resupinatum }\end{array}$ & $\begin{array}{l}\text { Peloponnisos, Mt. Aphrodisio, between Dafni and the crossroad to Nasia } \\
\text { village, roadsides, } 550-600 \mathrm{~m}, 26 \text { May } 2013\end{array}$ & 8673 \\
\hline Trifolium stellatum $\mathrm{L}$. & $\begin{array}{l}\text { Peloponnisos, Mt. Aphrodisio, ca. } 0.5 \mathrm{~km} \mathrm{SE} \text { of Dechouni village, forest } \\
\text { roadsides, } 850 \mathrm{~m}, 24 \text { May } 2013\end{array}$ & 8164 \\
\hline
\end{tabular}


Table 1. continued.

\begin{tabular}{|l|l|c|}
\hline Trifolium striatum L. & $\begin{array}{l}\text { Peloponnisos, Mt. Aphrodisio, between Dechouneika village and the } \\
\text { sanctuary of Aphrodite, road cuttings, 800 m, 26 May 2013 }\end{array}$ & 8822 \\
\hline Trifolium subterraneum L. & $\begin{array}{l}\text { Peloponnisos, Mt. Aphrodisio, ca. 1 Km S of Nasia village, forest roadsides, } \\
700-800 \mathrm{~m}, 26 \text { May 2013 }\end{array}$ & 8755 \\
\hline Trifolium suffocatum L. & $\begin{array}{l}\text { Attiki, Mt. Pendelikon, northern slopes of Megali Mavrinora, sparse } \\
\text { Quercus coccifera L. scrub, marbles, 550 m, 14 May 2008 }\end{array}$ & 4195 \\
\hline Trifolium tomentosum L. & $\begin{array}{l}\text { Attiki, NW part of Mt. Pendelikon, path margins near the chapel of Profitis } \\
\text { Ilias, 550 m, 10 May 2003 }\end{array}$ & 1378 \\
\hline
\end{tabular}

the smallest value of aspect ratio (1.1206) are observed in T. suffocatum. The longest seeds are observed in T. stellatum $(2.3333 \mathrm{~mm})$ which has one of the biggest aspect ratio (1.5908), forming elongated-ovoid seeds, while the most elongated seeds belong to $T$. cherleri (aspect ratio 1.6243). Both T. repens and T. subterraneum are characterised by a small aspect ratio with a prominent radical lobe, which makes them heart shaped (Fig. 5A1 and Fig. 6A1 respectively).

The main types of seed surface patterns recognised are the following: foveolate, reticulate, papillose, rugulate (rugose). Patterns with mixed characters also exist (Table 2).

One of the most common patterns observed is the "foveolate". However, this pattern is very diversified and, in some cases, obscured, observed only at a higher magnification. Each of the species belonging to this group of "foveolate" has a distinctive micromorphology. $T$. arvense and T. nigrescens exhibit the highest similarity in their seed coat surface characteristics. Together with $T$. grandiflorum they constitute a quite homogeneous subgroup within this type of pattern. The similarities of the aforementioned taxa though, are not justified by their affinities, as proposed by various infrageneric classifications. They are distantly related, as they belong to different sections as defined by Zohary \& Heller (1984).

T. hirtum, T. pignantii and T. angustifolium constitute another subgroup within this type of pattern. These species belong to the same section, but in different subsections (Zohary \& Heller 1984). In addition, seed coat surface of T. hirtum and T. pignantii exhibits many similarities with the one presented in Zohary \& Heller (1984) for Trifolium microcephalum Pursh, even though the latter species is native to western North America and belongs to section Involucrarium Hook., which includes only American species (Zohary \& Heller 1984).

T. hirtum and T. cherleri are closely related taxa, but they have very distinct seed coat patterns and they are easily distinguished based on this criterion. The same also applies for Trifolium repens and $T$. nigrescens.

On the other hand, the similarities observed in the seed coat surface of T. tomentosum and $T$. physodes justify their affinities proposed by classical methods.

T. aurantiacum, which is considered a Greek endemic (Dimopoulos \& al. 2013), has a peculiar pattern. The papillae of the seed surface are obscurely discerned owning to the overlying cuticular reticulum.

Some unusual micromorphological features that are observed in the examined species enhance the deviation from the patterns which have been described by now and increase considerably their diversity. These features are a criterion to distinct the investigated taxa 


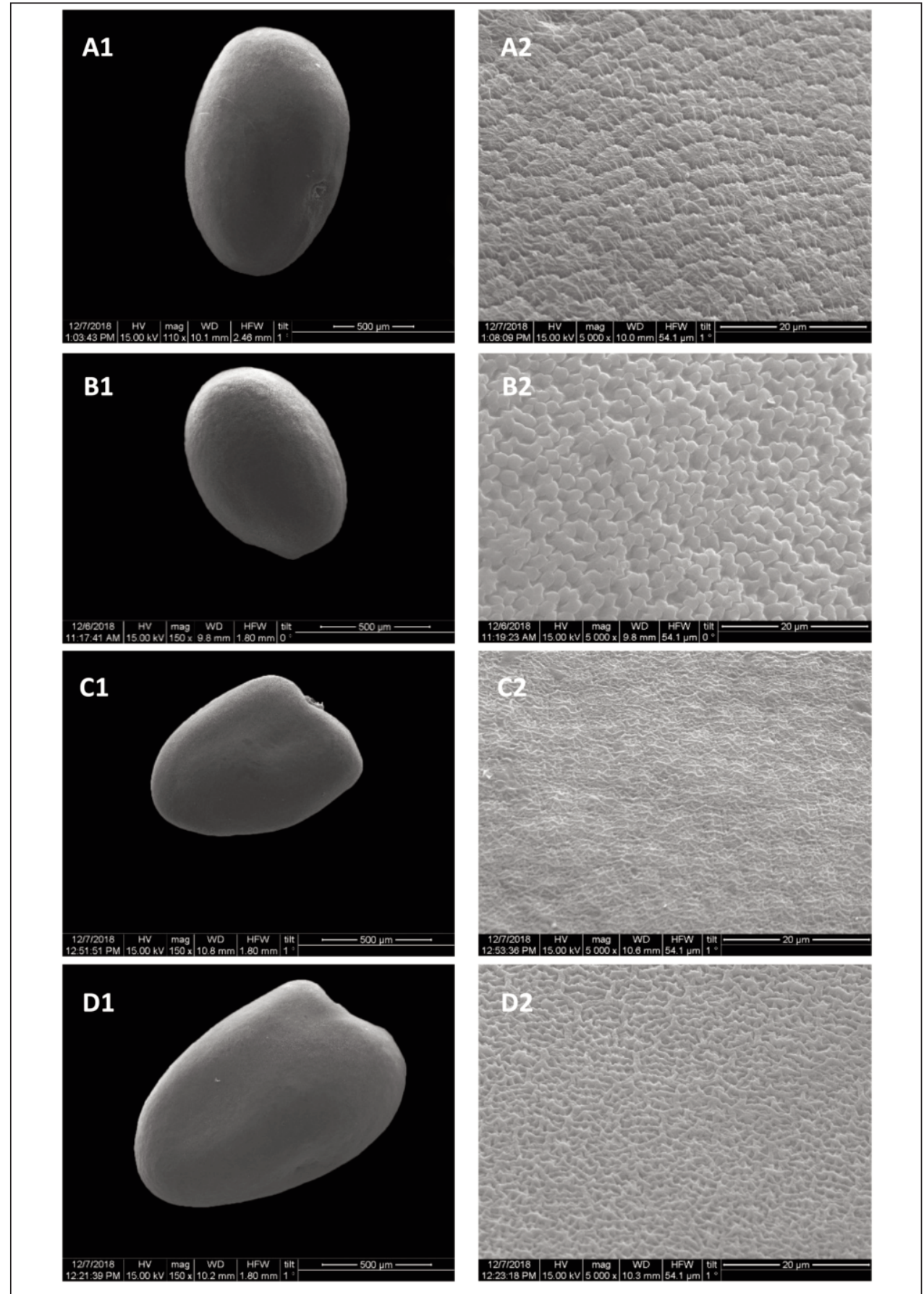

Fig. 1. 1. Seed overview; 2. seed coat surface micromorphology of: A) Trifolium angustifolium; B) T. arvense; C) T. aurantiacum; D) T. boissieri. 
252 Baliousis \& al.: Micromorphological study of some Trifolium taxa (Fabaceae) ...

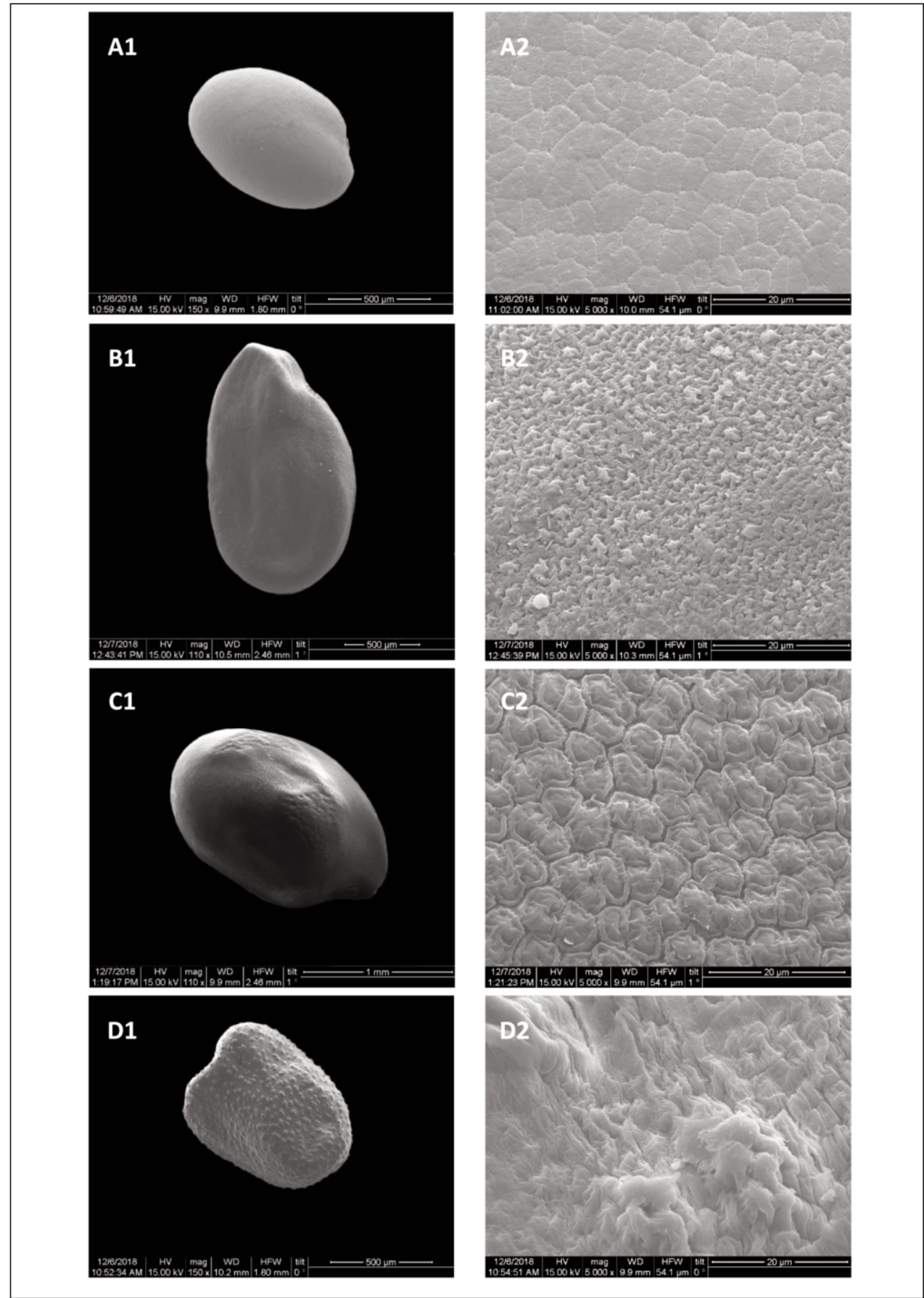

Fig. 2. 1. Seed overview; 2. seed coat surface micromorphology of: A) Trifolium campestre; B) T. cherleri; C) T. fragiferum; D) T. glomeratum. 

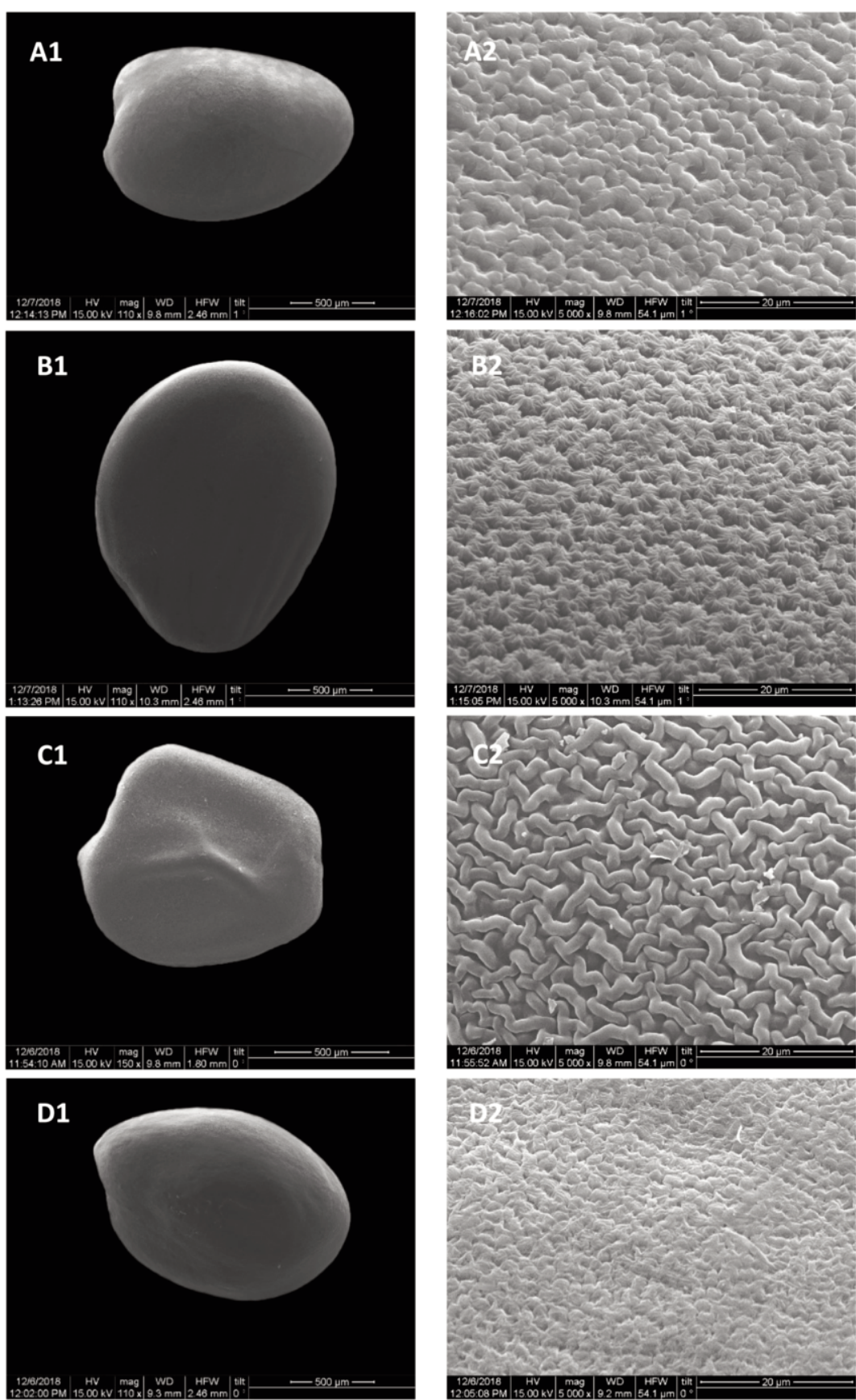

Fig. 3. 1. Seed overview; 2. seed coat surface micromorphology of: A) Trifolium grandiflorum; B) T. hirtum; C) T. lappaceum; D) T. leucanthum. 
254 Baliousis \& al.: Micromorphological study of some Trifolium taxa (Fabaceae) ...
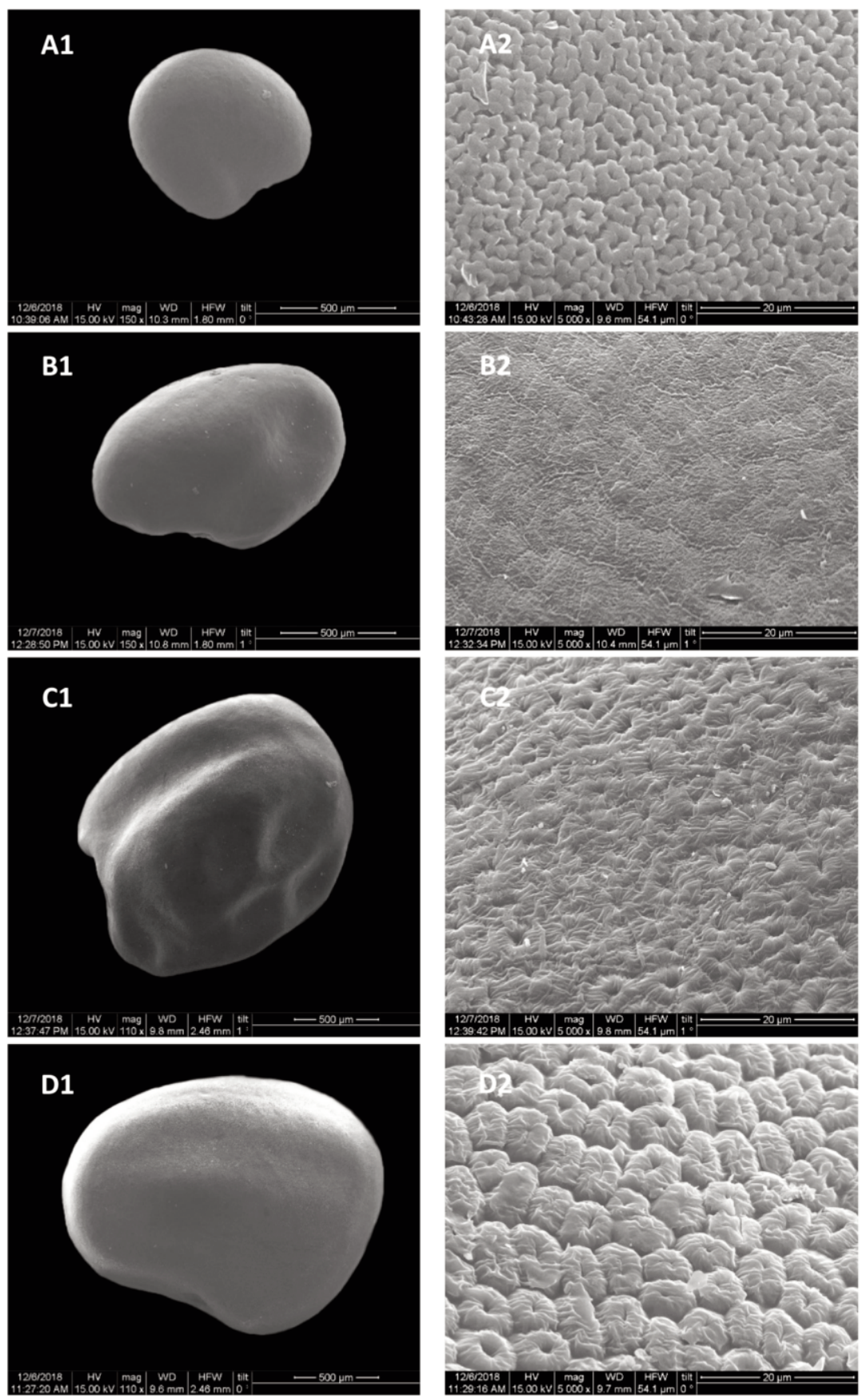

Fig. 4. 1. Seed overview; 2. seed coat surface micromorphology of: A) Trifolium nigrescens; B) T. patens; C) T. physodes; D) T. pignantii. 

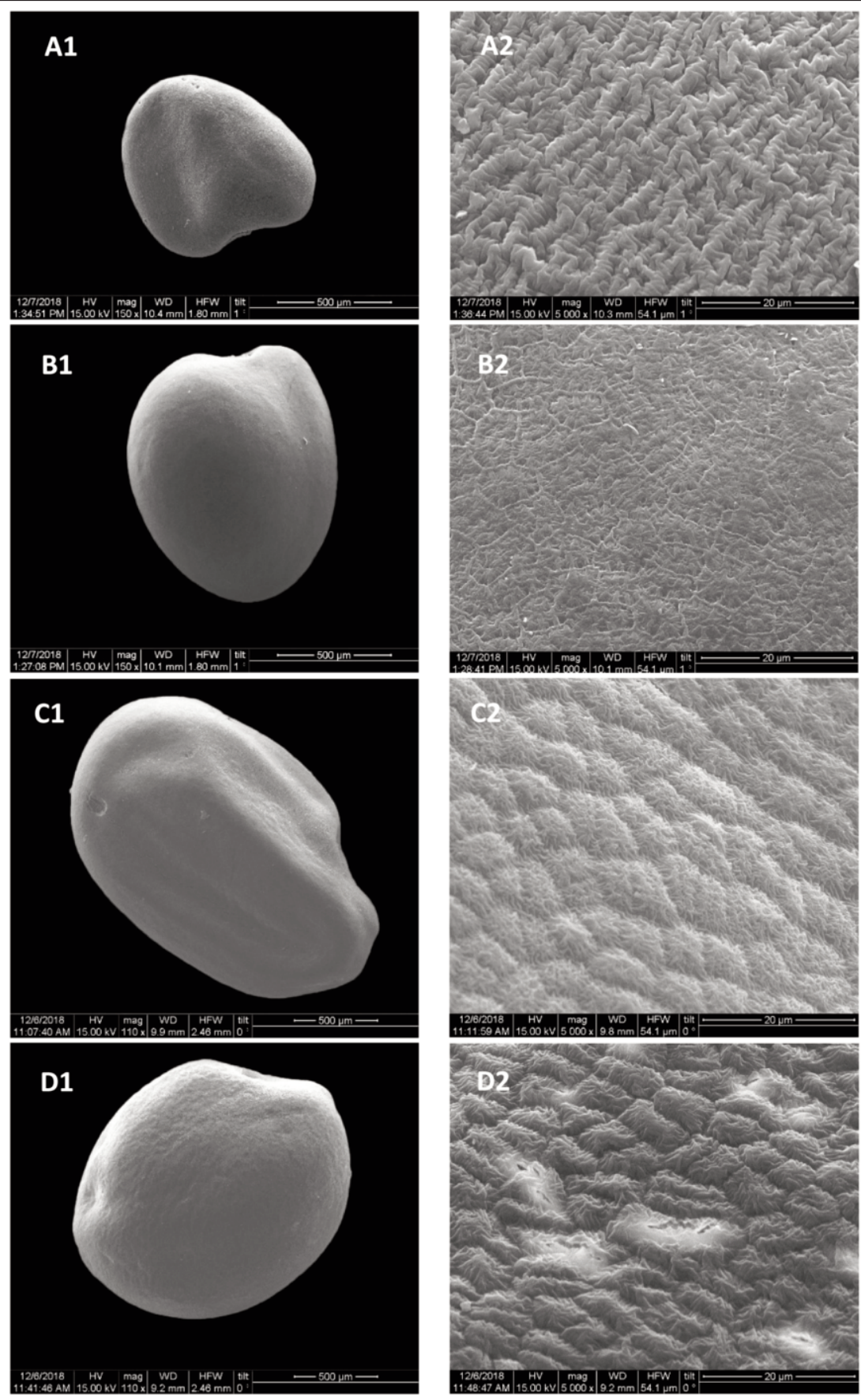

Fig. 5. 1. Seed overview; 2. seed coat surface micromorphology of: A) Trifolium repens; B) $T$. resupinatum subsp. resupinatum; C) T. stellatum; D) T. striatum. 
256 Baliousis \& al.: Micromorphological study of some Trifolium taxa (Fabaceae) ...
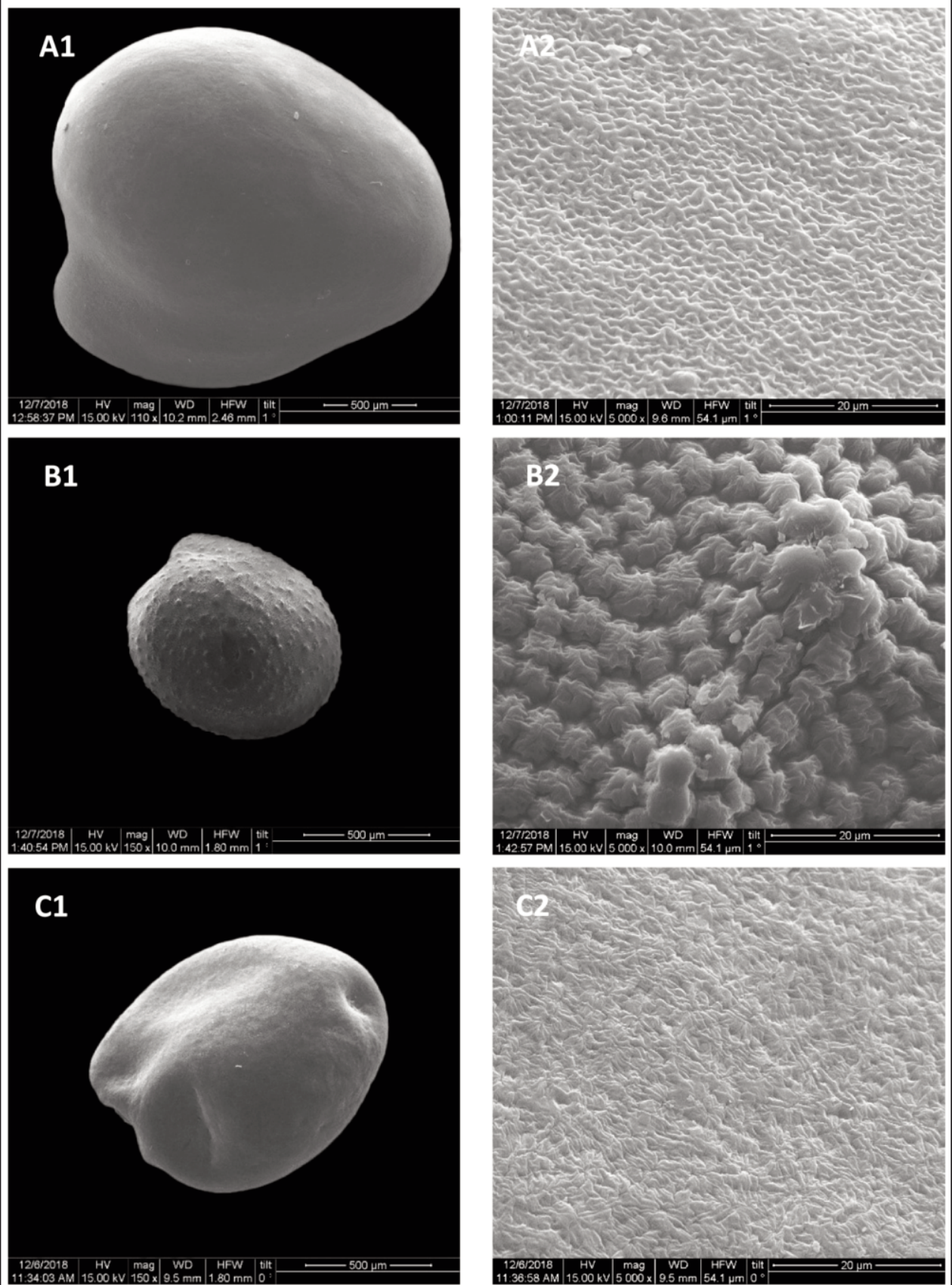

Fig. 6. 1. Seed overview; 2. seed coat surface micromorphology of: A) Trifolium subterraneum; B) T. suffocatum; C) T. tomentosum. 
Table 2. Seed characters of Trifolium species. The mean value of length and width in $\mathrm{mm}$ is given along with standard deviation (SD). Taxa studied for the first time are indicated with an asterisk $(*)$.

\begin{tabular}{|c|c|c|c|c|c|}
\hline Taxon & $\begin{array}{l}\text { Length } \\
\text { (SD) }\end{array}$ & $\begin{array}{l}\text { Width } \\
\text { (SD) }\end{array}$ & $\begin{array}{c}\text { Aspect } \\
\text { ratio (L/W) }\end{array}$ & $\begin{array}{l}\text { Seed } \\
\text { shape }\end{array}$ & Seed coat surface \\
\hline T. angustifolium & $\begin{array}{l}1.4881 \\
(0.0894)\end{array}$ & $\begin{array}{c}1.0127 \\
(0.0304)\end{array}$ & 1.4695 & $\begin{array}{l}\text { Elongated- } \\
\text { ovoid }\end{array}$ & $\begin{array}{l}\text { Foveolate } \\
\text { (obscurely) }\end{array}$ \\
\hline T. arvense & $\begin{array}{c}0.9053 \\
(0.0171)\end{array}$ & $\begin{array}{c}0.6388 \\
(0.0422)\end{array}$ & 1.4172 & $\begin{array}{l}\text { Elongated- } \\
\text { ovoid }\end{array}$ & Foveolate \\
\hline *T. aurantiacum & $\begin{array}{c}0.9596 \\
(0.0792)\end{array}$ & $\begin{array}{c}0.6793 \\
(0.0649)\end{array}$ & 1.4126 & $\begin{array}{l}\text { Elongated- } \\
\text { ovoid }\end{array}$ & $\begin{array}{l}\text { Low papillose } \\
\text { with overlying } \\
\text { cuticular } \\
\text { reticulum }\end{array}$ \\
\hline${ }^{*}$ T. boissieri & $\begin{array}{c}0.9044 \\
(0.1281) \\
\end{array}$ & $\begin{array}{c}0.7666 \\
(0.1476) \\
\end{array}$ & 1.1798 & Round & Multi-reticulate \\
\hline T. campestre & $\begin{array}{c}0.8904 \\
(0.0263)\end{array}$ & $\begin{array}{c}0.6092 \\
(0.0085)\end{array}$ & 1.4616 & $\begin{array}{l}\text { Elongated- } \\
\text { ovoid }\end{array}$ & $\begin{array}{l}\text { Foveolate } \\
\text { (obscurely) }\end{array}$ \\
\hline *T. cherleri & $\begin{array}{c}1.6133 \\
(0.0812) \\
\end{array}$ & $\begin{array}{c}0.9932 \\
(0.0154)\end{array}$ & 1.6243 & $\begin{array}{l}\text { Elongated- } \\
\text { ovoid }\end{array}$ & Rugulate \\
\hline T. fragiferum & $\begin{array}{c}1.6157 \\
(0.0209)\end{array}$ & $\begin{array}{c}1.2723 \\
(0.0714)\end{array}$ & 1.2699 & Ovoid & $\begin{array}{l}\text { Papillose } \\
\text { (irregular) }\end{array}$ \\
\hline T. glomeratum & $\begin{array}{c}0.8803 \\
(0.0238) \\
\end{array}$ & $\begin{array}{c}0.6580 \\
(0.0662)\end{array}$ & 1.3379 & Ovoid & $\begin{array}{l}\text { Obscure papillose } \\
\text { with mounds }\end{array}$ \\
\hline${ }^{*} T$. grandiflorum & $\begin{array}{c}1.5655 \\
(0.0547) \\
\end{array}$ & $\begin{array}{c}1.0788 \\
(0.0366) \\
\end{array}$ & 1.4512 & $\begin{array}{l}\text { Elongated- } \\
\text { ovoid }\end{array}$ & Foveolate \\
\hline$* T$. hirtum & $\begin{array}{c}1.8361 \\
(0.0654)\end{array}$ & $\begin{array}{c}1.3965 \\
(0.0860)\end{array}$ & 1.3148 & Ovoid & Foveolate \\
\hline *T. lappaceum & $\begin{array}{l}1.1338 \\
(0.0802)\end{array}$ & $\begin{array}{c}0.9510 \\
(0.0513)\end{array}$ & 1.1922 & Round & Multi-reticulate \\
\hline *T. leucanthum & $\begin{array}{l}1.6018 \\
(0.0669)\end{array}$ & $\begin{array}{l}1.1429 \\
(1.1022)\end{array}$ & 1.4015 & $\begin{array}{l}\text { Elongated- } \\
\text { ovoid }\end{array}$ & $\begin{array}{l}\text { Foveolate } \\
\text { (obscurely) }\end{array}$ \\
\hline T. nigrescens & $\begin{array}{c}1.3766 \\
(0.1055) \\
\end{array}$ & $\begin{array}{c}0.8812 \\
(0.0621)\end{array}$ & 1.5622 & $\begin{array}{l}\text { Elongated- } \\
\text { ovoid }\end{array}$ & Foveolate \\
\hline T. patens & $\begin{array}{c}1.0812 \\
(0.0294)\end{array}$ & $\begin{array}{c}0.7711 \\
(0.0581)\end{array}$ & 1.4022 & $\begin{array}{l}\text { Elongated- } \\
\text { ovoid }\end{array}$ & $\begin{array}{l}\text { Rugulate - } \\
\text { reticulate }\end{array}$ \\
\hline *T. physodes & $\begin{array}{c}1.7731 \\
(1.1502) \\
\end{array}$ & $\begin{array}{c}1.5123 \\
(0.0794) \\
\end{array}$ & 1.1724 & Round & Foveolate \\
\hline$* T$. pignantii & $\begin{array}{c}1.9324 \\
(0.0439)\end{array}$ & $\begin{array}{l}1.5643 \\
(0.0931)\end{array}$ & 1.2353 & Ovoid & Foveolate \\
\hline T. repens & $\begin{array}{c}0.8828 \\
(0.0002)\end{array}$ & $\begin{array}{c}0.7559 \\
(0.0012)\end{array}$ & 1.1679 & $\begin{array}{l}\text { Heart } \\
\text { shaped }\end{array}$ & Rugulate \\
\hline $\begin{array}{l}\text { T. resupinatum } \\
\text { subsp. resupinatum }\end{array}$ & $\begin{array}{c}1.1339 \\
(0.0223)\end{array}$ & $\begin{array}{c}0.9162 \\
(0.0445)\end{array}$ & 1.2376 & Ovoid & $\begin{array}{l}\text { Reticulate - } \\
\text { obscurely } \\
\text { foveolate }\end{array}$ \\
\hline T. stellatum & $\begin{array}{c}2.3333 \\
(0.1227)\end{array}$ & $\begin{array}{c}1.4667 \\
(0.1084)\end{array}$ & 1.5908 & $\begin{array}{l}\text { Elongated- } \\
\text { ovoid }\end{array}$ & Papillose - rugose \\
\hline T. striatum & $\begin{array}{c}1.7557 \\
(0.0451)\end{array}$ & $\begin{array}{l}1.4042 \\
(0.0553)\end{array}$ & 1.2503 & Ovoid & Papillose-rugose \\
\hline T. subterraneum & $\begin{array}{c}2.2052 \\
(0.1991) \\
\end{array}$ & $\begin{array}{c}1.9245 \\
(0.0752) \\
\end{array}$ & 1.1458 & $\begin{array}{l}\text { Heart } \\
\text { shaped }\end{array}$ & Multi-reticulate \\
\hline *T. suffocatum & $\begin{array}{c}0.8948 \\
(0.0669)\end{array}$ & $\begin{array}{c}0.7985 \\
(0.0383)\end{array}$ & 1.1206 & Round & $\begin{array}{l}\text { Papillose with } \\
\text { mounds }\end{array}$ \\
\hline T. tomentosum & $\begin{array}{c}1.2204 \\
(0.0455)\end{array}$ & $\begin{array}{c}0.9417 \\
(0.0629)\end{array}$ & 1.2960 & Ovoid & $\begin{array}{l}\text { Foveolate } \\
\text { (obscurely) }\end{array}$ \\
\hline
\end{tabular}


and may be proved useful for delimiting taxa with dubious status at species rank that have not been examined yet. Examining more species will enable us to reassess these patterns and to describe new ones.

The general appearance of the seed surface at low magnification $(43 \times$ and $150 \times)$ is tuberculate for $T$. suffocatum and T. glomeratum and smooth for the rest of the examined taxa. Thus, the examined species display two of the three relevant patterns found by Small $\&$ al. (1990) in the genus Medicago L.

There is a remarkable diversity in seed surface micromorphology of the examined species and each one has unique features making their classification a difficult task. As a result, seed surface characteristics are very suitable for the delimitation of taxa at species rank. According to the present study, seed micromorphological characters proved to be very useful for the delimitation and identification of the examined species, but generally the recognised patterns cannot support current taxonomic approaches at higher ranks. This is in agreement with the conclusions of other studies, such as Zohary \& Heller (1984) and Zorić \& al. (2010). However, there are some cases that infrageneric classification is supported by evidences derived from seed coat patterns. Thus, taxonomic implications of seed surface characters at ranks higher than species concern only some groups of species. Seed coat patterns cannot also support phylogenetic hypotheses nor do they reveal broader evolutionary trends as already stated by Lersten (1981).

The study will continue focusing mainly in pairs of taxa with dubious taxonomic status. Furthermore, the examination of more taxa will allow us to conduct the appropriate statistical analysis and draw broader conclusions. A more holistic approach of the study of the seed morphology and especially coat surface and its patterns will take into consideration not only its taxonomic and evolutionary significance, but its ecological-functional one too.

\section{References}

Dimopoulos, P., Raus, Th., Bergmeier, E., Constantinidis, Th., Iatrou, G., Kokkini, S., Strid, A. \& Tzanoudakis, D. (eds) 2013: Vascular plants of Greece: An annotated checklist. - Berlin \& Athens.

Ellison, N. W., Liston, A., Steiner, J. J., Williams, W. M. \& Taylor, N. L. 2006: Molecular phylogenetics of the clover genus (Trifolium-Leguminosae). - Molec. Phylogen. Evol. 39: 688-705. http://dx.doi.org/10.1016/j.ympev.2006.01.004

Lersten, N. R. 1979: A distinctive seed coat pattern in the Vicieae (Papilionoideae; Leguminosae).Proc. Iowa Acad. Sci. 86(3): 102-104.

- 1981: Testa topography in Leguminosae, subfamily Papilionoideae. - Proc. Iowa Acad. Sci. 88(4): 180-191.

— \& Gunn, C. R. 1982: Testa characters in tribe Vicieae, with notes about tribes Abreae, Cicereae, and Trifolieae (Fabaceae). - Agric. Res. Serv. U.S.D.A. Technical Bull. No. 1667.

Manning, J. C. \& van Staden, J. 1987: The systematic significance of testa anatomy in the Leguminosae - an illustrated survey. - S. African J. Bot. 53(3): 210-230.

Pinar, N. M., Büyükkartal, H. N. \& Çölgeçen, H. 2001: Pollen and seed morphology of diploids and natural tetraploids of Trifolium pratense L. (Leguminosae). - Acta Biol. Cracov., Ser. Bot. 43: 27-32.

Salimpour, F., Mostafavi, G. \& Sharifnia, F. 2007: Micromorphologic study of the seed of the genus Trifolium, section Lotoidea, in Iran. - Pakistan J. Biol. Sci. 10(3): 378-382. http://dx.doi.org/10.3923/pjbs.2007.378.382 
Samaropoulou, S., Baliousis, E. \& Bareka, P. 2019: Karyological study of eight Trifolium L. taxa from Greece. - Bot. Chron. 22: 159-170.

Scoppola, A., López Tirado, J., Manzano Gutiérrez, F. \& Magrini, S. 2018: The genus Trifolium (Fabaceae) in south Europe: a critical review on species richness and distribution. - Nord. J. Bot. 36: http://dx.doi.org/10.1111/njb.01723

Small, E., Brookes, B. \& Lassen, P. 1990: Circumscription of the genus Medicago (Leguminosae) by seed characters. - Canad. J. Bot. 68: 613-629.

Smýkal, P., Coyne, C. J., Ambrose, M. J., Maxted, N., Schaefer, H., Blair, M. W., Berger, J., Greene, S. L., Nelson, M. N., Besharat, N., Vymyslický, T., Toker, C., Saxena, R. K., Roorkiwal, M., Pandey, M. K., Hu, J., Li, Y. H., Wang, L. X., Guo, Y., Qiu, L. J., Redden, R. J. \& Varshney, R. K. 2015: Legume Crops Phylogeny and Genetic Diversity for Science and Breeding. - Crit. Rev. Pl. Sci. 34: 43-104. https://doi.org/10.1080/07352689.2014.897904

Taia, W. K. 2004: Tribe Trifolieae: Evidence from seed characters. - Pakistan J. Biol. Sci. 7(7): 1287-1302.

Zohary, M. \& Heller, D. 1984: The Genus Trifolium. - Jerusalem.

Zorić, L., Merkulov, L., Luković, J. \& Boža, P. 2010: Comparative seed morphology of Trifolium L. species (Fabaceae). - Period. Biol. 112(3): 263-272.

Addresses of the authors:

Evagelos Baliousis ${ }^{1}$, Sofia Samaropoulou ${ }^{2}$ \& Pepy Bareka²,

${ }^{1}$ Gortinias 2, Dionisos Attiki, GR-14569, Greece. E-mail: baliousisv@biol.uoa.gr

${ }^{2}$ Laboratory of Systematic Botany, Department of Crop Science, Agricultural University of Athens, GR-11855 Athens, Greece. E-mails: bareka@aua.gr; s.samarop@aua.gr 
